\title{
Mutual Inhibition of DNA Synthesis in $a$ - and $\alpha$-cells of Saccharomyces cerevisiae during Conjugation
}

\author{
By T. BILIŃSKI, W. JACHYMCZYK, J. LITWIŃSKA, \\ J. ŻUK AND W. GAJEWSKI \\ Institute of Biochemistry and Biophysics, Polish Academy of Sciences, \\ Warsaw, 02-532, Poland
}

(Received 17 August 1973; revised 5 November 1973)

SUMMARY

Isolation of $\alpha$ mating-type yeasts from a conjugation mixture permitted the direct demonstration of inhibition of DNA synthesis in these cells as a necessary prelude for zygote formation in yeast.

\section{INTRODUCTION}

Duntze, MacKay \& Manney (1970) and Bücking-Throm, Duntze, Hartwell \& Manney (I973) have demonstrated that $\alpha$-cells produce constitutively an $\alpha$-factor which inhibits the initiation of DNA replication in $a$-cells and thus synchronizes them. As yet there is no evidence that $a$-cells form an $a$-factor able to inhibit DNA replication in $\alpha$-cells. Hartwell (I973) has shown that only single, unbudding yeast cells of $a$ - and $\alpha$-type are able to fuse in the conjugation process.

Following our studies on the physiology of conjugation in yeast (Biliński, Litwińska, Żuk \& Gajewski, 1973) which enabled us to establish optimal conditions for conjugation and synchronous zygote formation, DNA synthesis has been studied in $\alpha$-cells separated from such a conjugation mixture.

\section{METHODS}

Strains. The following strains were used: M/s 2-I $\alpha$, leu ade-I and M/s 2-2 $a$ leu-I thr2-I; originating from the cross 55R5/3c a ural $\times$ S26I5B $\alpha \mathrm{thr}_{2-1} \operatorname{tyr}_{4}$, leuI, adeI, ade5. The strain 55R5 was obtained from Professor P. Slonimski, Gif-sur-Yvette, France, and strain S26 I 5B from Professor R. K. Mortimer, Donner Laboratory, University of California, Berkeley, U.S.A.

Media. For yeast culture YPG medium was used consisting of I \% Difco yeast extract, I $\%$ Difco-Bacto-Peptone and $2 \%$ glucose. For DNA synthesis assay a medium consisting of $0.2 \%$ yeast extract, $0.8 \%$ Bacto-peptone and $3 \%$ glucose, $\mathrm{pH}_{4.5}$ was used. For estimation of the number of $\alpha$ - and $a$-cells a minimal medium was used (Glazy \& Slonimski, 1957) with $2 \%$ glucose and enriched as required with leucine and adenine or with leucine, threonine and methionine.

Microscopical examination. The cells were counted in a haemacytometer under a light microscope. For estimation of synchronization, cells with and without buds were counted as single units and the ratio of budded cells to the total number of cells was calculated. The cells were sonicated twice for $30 \mathrm{~s}$, amplitude $2 \mu \mathrm{m}$, with an MSE I00 watt ultrasonic disintegrator, then cooled on ice and immediately counted. 
Culture. Both haploid strains were cultivated in $350 \mathrm{ml}$ Erlenmeyer flasks containing 100 $\mathrm{ml}$ of YPG medium for $\mathrm{I} 8 \mathrm{~h}$ at $30^{\circ} \mathrm{C}$ on an orbital shaker (I $20 \mathrm{rev} . / \mathrm{min}$ ). The concentration of cells in inocula was $3 \times 10^{5}$ for the $a$-strain and $2 \times 10^{6}$ for the $\alpha$-strain. Cells were harvested at the beginning of the stationary phase.

Conjugation. The procedure of Biliński et al. (1973) was used.

Determination of DNA synthesis. This was carried out according to Hatzfeld (1973).

Measurements of DNA radioactivity. Samples $(0.2 \mathrm{ml})$ containing DNA hydrolysates were mixed with $5 \mathrm{ml}$ methanol and $\mathrm{IO} \mathrm{ml}$ scintillation liquid [2, 5-diphenylonazole (PPO), I $3 \mathrm{~g}$, and I, 4-di-I, 2,5-phenylonazolyl-I-benzene (POPOP), I62.5 mg, in I I Packard scintillation grade toluene]. The radioactivity was assayed in a Liquid Scintillation Spectrometer Tricarb, Packard Model 3320.

Separation of yeast cells on Dowex $\mathrm{r} \times 4$ resin. Using the different abilities of various yeast strains to adsorb on Dowex I $\times 4$ resin (Biliński \& Litwińska, I974) we separated the $a$ - and $\alpha$-cells from the conjugation mixture. The mixture of $a$ - and $\alpha$-cells (prepared as described in Fig. 2) was centrifuged, suspended in 3 mM-sodium acetate, sonicated and diluted to a final volume of $17 \mathrm{ml}$. The $16 \mathrm{ml}$ samples of the suspension were added to flasks containing $5 \mathrm{~g}$ Dowex $\mathrm{I} \times 4$ in acetate form (washed with $70 \%$ ethanol and sterilized water and decanted). The flasks were incubated for $60 \mathrm{~min}$ on an orbital shaker. After incubation the contents were poured on to $2 \times 12 \mathrm{~cm}$ glass columns to separate the resin from the yeast suspension. The number of yeasts in the suspension collected under the columns was determined and the cells were plated on selective media to check the separation of mating types. Samples ( $10 \mathrm{ml}$ ) of this suspension were centrifuged and assayed for incorporation of radioactive adenine into DNA The solutions and yeast suspensions were kept on ice. The separation of yeasts from the suspension of resin was done at $4{ }^{\circ} \mathrm{C}$. Under these conditions the $\alpha$-strain was not adsorbed to the resin while the $a$-strain was strongly bound. After separation the contamination of $\alpha$-cells by $a$-cells was between 0.8 and $5.6 \%$.

\section{RESULTS AND DISCUSSION}

\section{Inhibition of budding in conjugation mixture}

Hartwell (1973) has shown that in conjugation mixtures nearly $85 \%$ of the cells are synchronized and unbudded. Using our procedure we observed nearly $96 \%$ of unbudded cells in the conjugation mixture which meant that the two mating types were reciprocally synchronized.

\section{$D N A$ synthesis in the conjugation mixture of $a$ - and $\alpha$-cells}

Figure I shows the result of a typical experiment. The inhibition of DNA synthesis distinctly precedes the fall in the percentage of yeasts with buds. This is understandable, since Hartwell's (I97I $a, b$ ) work has shown that DNA replication covers only $40 \%$ of the cell cycle, whereas buds start to form just after DNA synthesis initiation and separate only at the end of the cell cycle. In the present experiments stages of bud growth were not distinguished.

The inhibition of DNA replication in the conjugation mixture was quite conspicuous and suggests a mutual inhibition in both mating types. The residual level of incorporation of labelled adenine into DNA (about $20 \%$ of the control level) may represent the level of adenine incorporation into mitochondrial DNA. Throm \& Duntze (I970) suggested that the $\alpha$-factor inhibits only nuclear DNA synthesis in $a$-cells. 


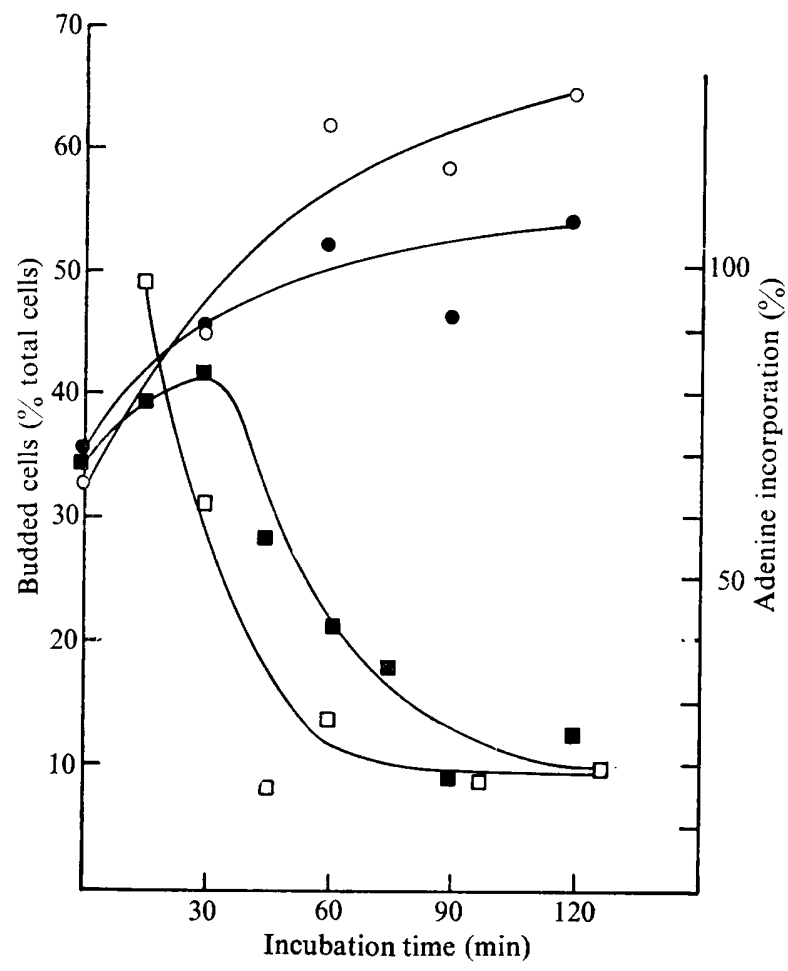

Fig. I. DNA replication and the percentage of budding cells in conjugation mixture of $a$ - and $\alpha$ yeasts. After $30 \mathrm{~min}$ adaptation to the medium the yeasts of both mating types were centrifuged and suspended in fresh medium at a density of $10^{8}$ cells $/ \mathrm{ml}$. Yeasts of both mating types were mixed in a I : I ratio and also incubated separately. Samples (I ml) were taken each 15 min and incubated with radioactive adenine $\left({ }^{3} \mathrm{H}-2\right.$, specific activity $17 \mathrm{Ci} / \mathrm{mm}$, The Radiochemical Centre, Amersham, Buckinghamshire) for the next $15 \mathrm{~min}$. They were then diluted with $\mathrm{I}$ ml medium enriched with $\mathrm{I} \mathrm{mg}$ of cold adenine $/ \mathrm{ml}$ and cooled on ice immediately. The radioactive samples were precipitated with trichloroacetic acid and treated as in Methods. Non-radioactive samples were sonicated and after tenfold dilution the percentage of budded cells was determined. $\bigcirc$, Budded $\alpha$-cells; 9 , budded $a$ cells; $\square$, budded cells in conjugation mixture; $\square$, radioactive adenine incorporation into DNA in conjugation mixture as compared to average incorporation in separately incubated suspensions of $a$ - and $\alpha$-yeasts. The differences in c.p.m. in DNA after $15 \mathrm{~min}$ of pulse in $10^{8}$ cells at the beginning and at the end of incubation were as follows:

$\begin{array}{lcc}\text { Strain } & \text { After I5 min } & \text { After I35 min } \\ \alpha & 397 & 2710 \\ a & 346 & 2130 \\ \text { Mixture } & 370 & 481\end{array}$

\section{Studies on budding and DNA synthesis in an $\alpha$-strain separated from the conjugation mixture}

As nothing is known about DNA inhibition in $\alpha$-cells in a conjugation mixture with $a$ cells, we separated the two kinds of yeast from the mixture by the method of adsorption on a Dowex resin $I \times 4$ (Biliński \& Litwińska, I974). Various yeast strains have different abilities to adsorb to the resins and this made possible a practically complete separation of the different components.

For comparison of DNA replication in $\alpha$-cells in the mixture with that in $a$-cells and $\alpha$ cells incubated alone in identical conditions, we followed incorporation of labelled adenine 


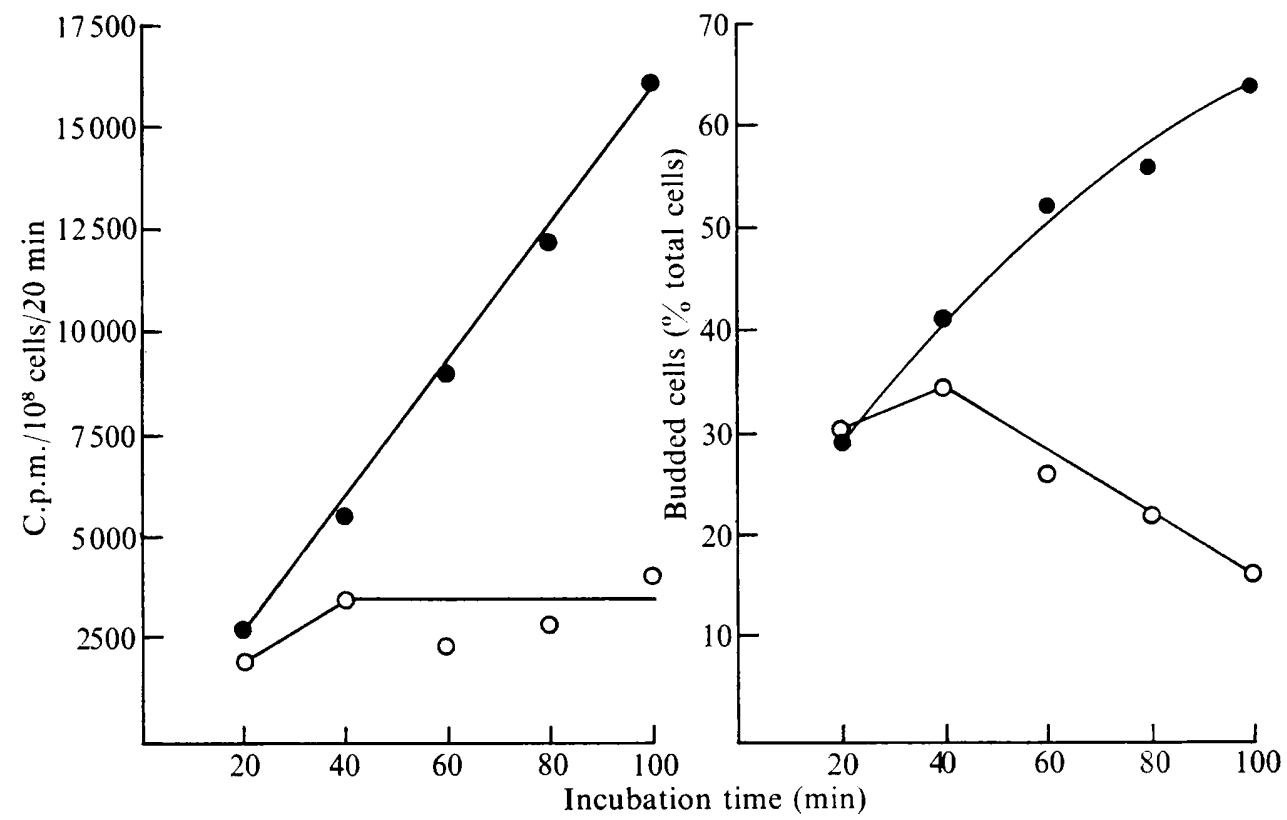

Fig. 2. DNA replication and cell budding in $\alpha$-cells isolated from conjugation mixture (O) and from a control non-conjugating mixture (O). Experimental conditions were as for Fig. I. Samples were taken at $20 \mathrm{~min}$ intervals and $3 \mathrm{ml}$ samples incubated for 20 min with $20 \mu \mathrm{Ci}$ radioactive adenine. After 20 min of incubation they were cooled on ice and diluted with $1 \mathrm{ml}$ medium supplemented with $3 \mathrm{mg}$ cold adenine $/ \mathrm{ml}$. A control mixture was obtained by mixing $2 \mathrm{ml}$ of cooled suspensions of $a$ - and $\alpha$-cells after adenine incorporation. Both mixtures were then separated on resins, the radioactivity of DNA was measured and the number of budding cells counted.

(20 min pulse of radioactive adenine) in the conjugation mixture and in cultures of both mating types cultivated separately. To eliminate the possible influence of separation on resin columns, both strains were mixed after exposure to radioactive adenine and the same procedure of separation on resin was applied. The cells incubated separately showed continuous increase in the budding fraction during the period of incubation, whereas the $\alpha$-cells from the conjugation mixture after a short period of increase showed a continuous fall in the fraction of budding cells (Fig. 2).

The inhibition of DNA replication in the $\alpha$-strain was noticeable within the first $20 \mathrm{~min}$, and after $60 \mathrm{~min}$ remained constant at $26 \%$ of the control level. The results resemble those shown in Fig. I and suggest that the process of synchronization is very similar in both mating types.

Our results supported Hartwell's (1973) and Yanagishima's (1973) suggestions that a mutual synchronization of both $a$ - and $\alpha$-cells occurs in the conjugation mixture and that inhibition of DNA replication in $\alpha$-cells during conjugation is parallel to that known already for $a$-type cells.

This work was supported by the Polish Academy of Sciences within the project 0.9.3.I. 


\section{REFERENCES}

BiLiŃSKI, T., LiTwiŃSKA, J., ŻUK, J. \& GAJEWSKI, W. (I973). Synchronization of zygote production in Saccharomyces cerevisiae. Journal of General Microbiology 79, 285-292.

BıLı́́SKI, T. \& LITwIŃSKA, J. (1974). The various binding affinities of Dowex $\mathrm{I}$ resin of some strains of Saccharomyces cerevisiae. Bulletin de l'Académie Polonaise des Sciences 22 (in the Press).

Bücking-Throm, E., Duntze, W., Hartwell, H. \& Manney, T. R. (1973). Reversible arrest of haploid yeast cells at the initiation of DNA synthesis by a diffusible sex factor. Experimental Cell Research 76, 99-IIO.

Duntze, W., MacKay, V. \& Manney, T. R. (1970). Saccharomyces cerevisiae. A diffusible sex factor. Science, New York 168, I472-I473.

Galzy, P. \& Slonimski, P. P. (1957). Variations physiologiques de la levure au cours de la croissance sur l'acide lactique ou sur glucose comme seule source de carbone. Comptes rendus des séances de l'Académie des sciences $\mathbf{2 4 5}, \mathbf{2 4 2 3}$.

HarTwell, L. H. (I97I $a$ ). Genetic control of the cell division cycle in yeast. II. Genes controlling DNA replication and its initiation. Journal of Molecular Biology 59, 183-194.

HaRTwell, L. H. (I97I $b$ ). Genetic control of the cell division cycle in yeast. IV. Genes controlling bud emergence and cytokinesis. Experimental Cell Research 69, 265-276.

Hartwell, L. H. (1973). Synchronization of haploid yeast cell cycles, a prelude to conjugation. Experimental Cell Research 76, I I I-I 7 .

HATZFeLD, J. ( I 973). DNA labelling and its assay in yeast. Biochimica et biophysica acta 299, 34-42.

Throm, E. \& DUNTZE, W. (1970). Mating-type dependent inhibition of deoxyribonucleic acid synthesis in Saccharomyces cerevisiae. Journal of Bacteriology 104, I388-1 390.

Yanagishima, N. (1973). Yeast. A New's Letter for Persons Interested in Yeast. Edited by H. J. Phaff. The International Commission on Yeast and Yeast-like Microorganisms of the IAMS. 